\title{
Gonadal hormones level and morphometric traits in cow deliveres twin and single calves
}

\author{
T. Yuwono, I. Sumeidiana, Y. S. Ondho and E. Kurnianto \\ Faculty of Animal and Agricultural Sciences, Diponegoro University, \\ Tembalang Campus, Semarang 50275 - Indonesia \\ CorrespondingE-mail: kurniantoedy17@gmail.com \\ Received March 27, 2017; Accepted May 18, 2017
}

\begin{abstract}
ABSTRAK
Penelitian ini bertujuan untuk mengetahui level follicle stimulating hormone (FSH) dan luteinizing hormone (LH) dari 4 kelompok induk sapi dengan tiga ulangan yang terdiri dari : induk sapi Peranakan Ongole beranak kembar (POBK), induk sapi Peranakan Ongole beranak tunggal (POBT), induk sapi keturunan Simmental beranak kembar (KSBK) dan induk sapi keturunan Simmental beranak tunggal (KSBT). Perbandingan ukuran morfometri induk sapi antara lain : bobot badan, lingkar dada, tinggi pundak, panjang badan dan lingkar perut. Sapi dipelihara oleh petani yang tersebar di Kabupaten Kendal dan Grobogan, Provinsi Jawa Tengah. Sampel darah diambil saat estrus, dan serumnya diuji dengan metode Enzyme Linked Fluorescent Assay (ELFA) menggunakan alat Vidas dari BioMềrieux, Inc. Uji-t digunakan untuk membandingkan konsentrasi FSH dan LH antara induk sapi POBK, POBT, KSBK dan KSBT. Hasil analisis menunjukkan tidak ada perbedaan konsentrasi FSH dan LH saat estrus antara induk sapi POBK, POBT, KSBK dan KSBT. Level FSH dan LH yang rendah pada seluruh induk sapi yang diteliti berkaitan dengan periode menyusui, ketika sekresi prolaktin periodik menekan sekresi FSH dan LH.
\end{abstract}

Kata Kunci : sapi betina, hormon gonadal, morfometri, kelahiran kembar

\begin{abstract}
The objectives of study were to investigate follicle stimulating hormone (FSH) and luteinizing hormone (LH) level in four groups beef cow composed of Ongole Grade cow delivered twinning calves (OGT), Ongole Grade cow delivered single calf (OGS), Simmental crossbred cow delivered twinning calves (SCT) and Simmental crossbred cow delivered single calf (SCS). Morphometric traits included body weight, heart girth, body length, shoulder height, and abdominal circumference were taken from cows. Cows were reared by farmers in Grobogan and Kendal Regency, Central Java. Blood serums of cows were taken at estrus. FSH and LH concentration were measured with enzyme linked fluorescent assays (ELFA) technique. FSH and LH concentration were compared between OGT, OGS, SCT, and SCS. Result showed that there were no significant difference of FSH and LH concentration between OGT and OGS, between OGT and SCT, between OGT and SCS. There were no significant difference between OGS and SCT, and OGS and SCS. There were no significant difference between SCT and SCS. Low concentration of FSH and LH in all cows was related to suckle period, when prolactin concentration was inversely related to FSH and LH concentration.
\end{abstract}

Keywords : cow, gonadal hormones, morphometric, twinning birth 


\section{INTRODUCTION}

Twinning was scarcely happen in cow, because cattle were monotocous species. The only one follicle developed became dominant and suppressed the others became regress and athroped, only one egg will be released at each estrus, (Hafez, 2001; Noseir, 2003). There was evidence about effect of gonadal hormone to cow delivered twinning calves (Acosta et al., 2005). Gonadal hormones of follicle stimulating hormone (FSH) and luteinizing hormone ( $\mathrm{LH})$ played important role to support the twinning birth in relationship with estrus and follicular development. FSH regulated estrus cycle, stimulated the early growth and development of primordial follicle, recruit and selection follicles became dominant follicle before ovulation (Hess et al., 2005; Gilbert et al., 2011) and LH stimulated maturation of dominant follicle to ovulate (Hafez, 2001; Rodgers and Rodgers, 2010). Double ovulation with two dominant follicles that growth in same rate was called deviation (Wiltbank et al., 2000; Acosta et al., 2005).

The objectives of study were to investigate the difference level of FSH and LH of Ongole Grade delivered twinning calves, Ongole Grade delivered single calf, Simmental crossbred delivered twinning calves, and Simmental crossbred delivered single calf to understand the influence of hormones level to twinning birth. Morphometric traits that were body weight, heart girth, shoulder height, body length and abdominal circumference were given as additional description.

\section{MATERIALS AND METHODS}

\section{Experimental Animals}

Animal research for gonadal hormones composed of four groups: Ongole Grade cow delivered twinning calves (OGT), Ongole Grade cow delivered single calf (OGS), Simmental crossbred cow delivered twinning calves (SCT), and Simmental crossbred cow delivered single calf (SCS) with three cows in every group. Animal research for morphometric traits composed of four groups: seven heads of OGT, thirteen heads of OGS, seven heads of SCT and seven heads of SCS. All cows were reared by farmers in the same stall or two nearby stalls, spreading in five villages in Grobogan and Kendal Residence, Central Java, Indonesia.

\section{Measurement}

Four morphometric traits observed were heart girth, body length, shoulder height and abdominal circumference taken on individual cow by using of animal measurement tool ANImeter. Body weight was estimated by using Schoorl formulation (Santoso, 1995):

Estimated Body Weight $=\left[(\mathrm{HG}+22)^{2} / 100\right]$

Where HG was Heart girth. Heart girth was measured as body circumference just behind the forelegs. Body length measured from the point of shoulder to the point of pine bone. Shoulder height was measured from the point of shoulder (thoracic vertebrae) to the ground. Abdominal circumference was measured as body circumference just in front of behind legs

\section{Blood Collection}

Blood samples were taken at jugular vein by spuit five cc for each cow taken during estrus period. Blood sample in disposable syringe was placed in angle position at room temperature until coagulant and then placed into coller bag. In the commercial laboratory, serum was separated by centrifuge at 3,500 rpm for three minutes. FSH and LH concentration in blood serum were measured by using miniVIDAS ${ }^{\circledR}$ Immunoassay Analyzer, product of Biomerieux with Enzyme Linked Fluorescent Assays (ELFA) technique.

\section{FSH and LH Assays}

The assay principle combines two steps of enzyme immunoassay sandwich method with a final fluorescent detection (ELFA). The Solid Phase Receptable (SPR), serves as the solid phase as well as the pipetting device for the assay. Reagents for the assay were ready to use and predispend in the sealed reagent strips. All of the assay steps were performed automatically by the instrument. The sample was cycled in and out of the SPR several times. This operation enables the monoclonal antibody fixed onto the interior wall of the SPR to capture the free fraction of the FSH/LH antigen present in the sample. Unbound components were eliminated during the washing steps. The alkaline phosphatase labeled monoclonal antibody was then incubated in the SPR where it bound with the FSH/LH antigen. Unbound conjugate was then eliminated during the washing steps. During the final detection step, the substrate (4-Methyl-umbelliferyl phosphate) was cycled in and out of the SPR. The conjugate enzyme catalyzes the hydrolysis of this substrate into a fluorescent product (4-Methyl- 
umbelliferone) the fluorescent of which was measured at $450 \mathrm{~nm}$. The intensity of the fluorescence was proportional to the concentration of $\mathrm{FSH} / \mathrm{LH}$ antigen free fraction present in the sample. At the end of the assay, results were automatically calculated by the VIDAS instrument in relation to the calibration curve stored in memory, and then was printed out.

The objectives of this study were to elucidate the gonadal hormone level in Ongole Grade and Simmental crossbred delivering twin and single calves, by using t-test (Steel and Torrie, 1981).

\section{RESULTS AND DISCUSSION}

\section{Morphometric Traits}

Table 1 shows that average body weight of OGT $(369.60 \pm 37.96 \mathrm{~kg})$ was highly significantly different $(\mathrm{P}<0.05)$ from OGS $(322.02 \pm 51.75 \mathrm{~kg})$, OGT had higher physiological need to develop double pregnancies, accumulated placental mass and prepared postpartum suckled period. OGT elevated feeding to meet physiological need and caused the increase of body weight. Ecternkamp and Gregory (1999) explained that cow delivered single calf has lower body weight than cow delivered twinning calves, at the time between partus and first mating postpartum.

Average abdominal circumference of OGT $(202.29 \pm 18.55 \mathrm{~cm})$ was highly significantly different $(\mathrm{P}<0.05)$ than those of OGS $(187.31 \pm$ $13.58 \mathrm{~cm})$. In this study, there were high relationship between body weight and abdominal circumference. There were two function of stomach in cow. First, as site of digestive system where consumption activity increased during pregnancies, second, as site of pregnancies where the fetuses were growing until birth. OGT had bigger stomach size than OGS and followed by higher of body weight, tendon mass, meat, bone and fat in that area. Morphometric comparative of Ongole Grade and Simmental Crossbred delivered twin and single calves are presented in Table 1.

Average heart girth, body length and shoulder height were not different between OGT and OGS caused by estrogenic hormone activity in cow that decrease the growth of bone after puberty.

Average body weight of SCT $(421.29 \pm 9.95$ $\mathrm{kg})$ was highly significantly different $(\mathrm{P}<0.05)$ from SCS $(395.17 \pm 35.14 \mathrm{~kg})$. Highly average body weight of SCT caused by developed of two embryos so that occurred accumulated placental mass, liquid and growth of abdominal region to support pregnancy.

\section{FSH Concentration}

Statistical analysis showed that FSH concentration of OGT $(0.16 \pm 0.06 \mathrm{ng} / \mathrm{mL})$ was not difference from OGS $(0.14 \pm 0.06 \mathrm{ng} / \mathrm{mL})$, $\operatorname{SCT}(0.11 \pm 0.01 \mathrm{ng} / \mathrm{mL})$, and SCS $(0.51 \pm 0.50$ $\mathrm{ng} / \mathrm{mL})$. FSH concentration of OGS $0.14 \pm 0.06$ $\mathrm{ng} / \mathrm{mL})$, was not different from SCT $(0.11 \pm 0.01$ $\mathrm{ng} / \mathrm{mL})$, and SCS $(0.51 \pm 0.50 \mathrm{ng} / \mathrm{mL})$. FSH concentration of SCT $(0.11 \pm 0.01 \mathrm{ng} / \mathrm{mL})$ was not different from SCS $(0.51 \pm 0.50 \mathrm{ng} / \mathrm{mL})$.

Table 1. Morphometric Comparative of Ongole Grade and Simmental Crossbred Delivered Twin and Single Calves

\begin{tabular}{lccccc}
\hline \multirow{2}{*}{ Parameters } & \multicolumn{2}{c}{ Ongole Grade } & & \multicolumn{2}{c}{ Simmental Crossbred } \\
\cline { 2 - 3 } \cline { 6 - 6 } & Twin $(\mathrm{n}=7)$ & Single $(\mathrm{n}=13)$ & & Twin $(\mathrm{n}=7)$ & Single $(\mathrm{n}=7)$ \\
\hline Age (years) & $6.71 \pm 0.44$ & $6.31 \pm 1.64$ & & $6.14 \pm 1.35$ & $5.29 \pm 1.28$ \\
Parity (times) & $3.57 \pm 0.90$ & $2.85 \pm 1.24$ & & $3.14 \pm 0.64$ & $3.29 \pm 1.03$ \\
Body weight $(\mathrm{kg})$ & $369.60 \pm 37.96^{\mathrm{a}}$ & $332.02 \pm 51.75^{\mathrm{b}}$ & & $421.29 \pm 9.95^{\mathrm{a}}$ & $395.17 \pm 35.14^{\mathrm{b}}$ \\
Heart girth $(\mathrm{cm})$ & $170.00 \pm 9.89$ & $159.62 \pm 14.94$ & & $183.14 \pm 6.47$ & $176.57 \pm 8.88$ \\
Body length $(\mathrm{cm})$ & $136.57 \pm 19.71$ & $134.92 \pm 17.84$ & & $142.57 \pm 15.37$ & $133.00 \pm 11.92$ \\
Shoulder height $(\mathrm{cm})$ & $127.86 \pm 6.62$ & $129.08 \pm 13.39$ & & $130.71 \pm 6.67$ & $135.43 \pm 11.09$ \\
Abdominal circumference & $202.29 \pm 18.55^{\mathrm{a}}$ & $187.31 \pm 13.58^{\mathrm{b}}$ & & $219.14 \pm 23.96$ & $208.86 \pm 16.86$ \\
(cm) & & & & & \\
\hline
\end{tabular}

${ }^{\mathrm{ab}}$ Means in the same row for each parameter with different superscript are significantly different $(\mathrm{P}<0.05)$. 
Table 2. Analysis of FSH and LH Concentrations in Ongole Grade and Simmental Crossbred Delivered Twin and Single Calf

\begin{tabular}{|c|c|c|c|c|}
\hline \multirow{2}{*}{ Hormones } & \multicolumn{2}{|c|}{ Ongole Grade } & \multicolumn{2}{|c|}{ Simmental Crossbred } \\
\hline & Twin & Single & Twin & Single \\
\hline & ---------------- & 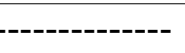 & ------------. & - \\
\hline FSH & $0.16 \pm 0.06$ & $0.14 \pm 0.06$ & $0.11 \pm 0.01$ & $0.51 \pm 0.50$ \\
\hline LH & $0.37 \pm 0.36$ & $0.38 \pm 0.39$ & $0.31 \pm 0.29$ & $0.36 \pm 0.33$ \\
\hline
\end{tabular}

All of cattle used as samples were 3 heads.

Analysis of FSH dan LH concentrations are presented showed in Table 2.

FSH concentration at estrus of OGT was not different from OGS. This result was different from Aryogi (2012) that explained if Ongole Grade delivered twinning calves naturally had higher FSH concentration than Ongole Grade delivered single calf. To produce double ovulation and twinning pregnancies were needed FSH concentration at high level. The level was not reached at every onset of estrus. Low FSH concentration several days before estrus as a purposed only one primordial follicle would grow and develop became graafian follicle to ovulate.

FSH concentration of OGT was not different from SCT. Shioya and Tomizuka (1999) explained that very high FSH concentration almost occurred in cow with history of twinning calves that will deliver twinning calves again, but the level did not higher enough if the cow will deliver single calf.

FSH concentration of SCT was not different from SCS. Low FSH concentration of SCT presumable of high intensity suckled of twin calves, caused pituitary gland to release prolactin in shorter duration. Prolactin activity was irreversible with FSH level.

\section{LH Concentration}

Statistical analysis showed that $\mathrm{LH}$ concentration of OGT $(0.37 \pm 0.36 \mathrm{ng} / \mathrm{mL})$ was not different from OGS $(0.38 \pm 0.39 \mathrm{ng} / \mathrm{mL})$, SCT $(0.31 \pm 0.29 \mathrm{ng} / \mathrm{mL})$, and SCS $(0.36 \pm 0.33$ $\mathrm{ng} / \mathrm{mL})$. LH concentration of OGS $(0.38 \pm 0.39$ $\mathrm{ng} / \mathrm{mL})$ was not different from SCT $(0.31 \pm 0.29$ $\mathrm{ng} / \mathrm{mL})$ and SCS $(0.36 \pm 0.33 \mathrm{ng} / \mathrm{mL})$. LH concentration of SCT $(0.31 \pm 0.29 \mathrm{ng} / \mathrm{mL})$ was not different from SCS $(0.36 \pm 0.33 \mathrm{ng} / \mathrm{mL})$.

LH concentration of OGT was not different from OGS. LH concentration increase between mid luteal phase and follicular phase that useful to produce LH and then decreased after LH surge (Kawate et al., 2001). Blood sample was taken after LH surge presumable given low LH concentration.

LH concentration of OGT was not different from SCT. Suckled activity disturbed the hypothalamus to release gonadothropin releasing hormone $(\mathrm{GnRH})$ so that suppressed the release of LH wave in cow delivered twinning calves (Montiel and Ahuja, 2005).

LH concentration of SCT was not different from SCS. Higher LH concentration at estrus indicated high activity of LH followed estrogen concentration. LH concentration was low and not different between SCT and SCS indicated did not occurred pregnancies after ovulation, and $\mathrm{LH}$ returned to role stimulated ovaries produced estrogen and progesterone and prepared next estrus cycle. LH concentration of OGS was not different from SCS. LH level of OGS was low and was not different from SCS indicated normal secretion of LH with only one dominant follicle ovulated after LH surge.

\section{CONCLUSIONS}

Body weight of Ongole Grade and Simmental crossbred cows delivered winning calves were highly significant different from those delivered single. Abdominal circumference of Ongole grade cow delivered winning calves were highly significantly different from those delivered single. The differences caused by higher physiological need to develop twin fetuses and prepared for suckling period. The gonadal hormones level of Ongole grade and Simmental crossbred cows delivered twinning calves were not different from those delivered single, caused by prolactin activity suppressed gonadal 
hormones.

\section{REFERENCES}

Acosta, T. J., M.A. Beg and O.J. Ginther. 2005. Effect of modified FSH surge on follicle selection and codominance in heifers. Anim. Reprod. 2(1):28-40.

Aryogi. 2012. Produktivitas Sapi Peranakan Ongole Induk Beranak Kembar secara Alami. (Dissertation). Gadjah Mada University, Yogyakarta. (Indonesian).

Echternkamp, S.E. And K.E. Gregory. 1999. Effects of twinning on gestation length, retained placenta, and dystocia. J Anim Sci. 77:39-47.

Gilbert, I., C. Robert, S. Dieleman, P. Blondin and M.A. Sirard. 2011. Transcriptional effect of the LH surge in bovine granulose cells during the peri-ovulation period. Reprod. 141(2):193-205.

Hafez, E. S. E. 2001. Physiology of Reproduction Hormones, Growth Factor and Reproduction. In Hafez, E. S. E. (Ed). Reproduction in Farm Animals. $7^{\text {th }}$ Ed. Lea \& Febiger, Philadelphia.

Hess, B. W., S. L. Lake, E. J. Scholljegerdes, T. R. Weston, V. Nayigihugu, J. D. C. Molle and G. E. Moss. 2005. Nutritional controls of beef cow reproduction. J. Anim. Sci. 83(E. Suppl.): E90-E106.

Kawate, N., M. Akiyama, T. Suga, T. Inaba, H.
Tamada, T. Sawada and J. Mori. 2001. Change in concentrations of luteinizing hormone subunit messenger ribonucleic acids in the estrous cycle of beef cattle. Anim. Reprod. Sci. 68:13-21.

Montial, F. and C. Ahuja. 2005. Body condition and suckling as factors influencing the duration of postpartum anestrus in cattle: a review. Anim. Reprod. Sci. 8:1-26.

Noseir, W. M. B. 2003. Ovarian follicular activity and hormonal profile during estrous cycle in cows: the development of 2 versus 3 waves. Reprod. Biol. Endocrinol. 1:50.

Rodgers, R. J. and H. F. I. Rodgers. 2010. Morphological classification of bovine ovarian follicles. Reprod. 139(2):309-318.

Santoso, U. 1995. Tata Laksana Pemeliharaan Ternak. Penebar Swadaya. Jakarta.

Shioya, Y. and T. Tomisuka. 1999. Twin calving inducted by the control of number of ovulations using an ultrasound scanning scope and aspiration of follicles. J. Mamm. Ova. Res. 16: 16-18.

Steel, R.G.D dan J.H. Torrie. 1981. Principles and Procedures of Statistics, a Biometrical Approach. International Student Ed. McGraw-Hill Book Company.

Wiltbank, M. C., P. M. Fricke, Sangsritavong, R. Sartori and O. J. Ginther. 2000. Mechanisms that prevent and produce double ovulations in dairy cattle. J. Dairy Sci. 83: 2998-3007. 